\title{
A Study on Educational Requirement of Forensic Medicine for Biomedical Laboratory Science
}

\author{
Se-Hoon Jung \\ Department of Neurology, Daegu Fatima Hospital, Daegu 41199, Korea
}

\section{임상병리학과 학생들의 법의학 교육의 요구도에 관한 연구}

\author{
정세훈 \\ 대구파티마병원 신경계검사실
}

\begin{abstract}
In order to find out a method to improve awareness of biomedical laboratory science about forensic medicine education and suggest a plan for invigoration, we carried out a survey targeting 100 students of biomedical laboratory science of Daegu Health College in Daegu region and implemented their awareness and requirement forensic medicine subject, which suggested very high awareness of most of the students about forensic medicine as a result. Out of 100 respondents, in the result of survey for students' awareness of forensic medicine, 94 (94\%) answered that they were aware of it, We could find that they have high expectation from forensic medicine, and current biomedical laboratory science showed very high awareness and requirement for forensic medicine education. Therefore, rather than focusing only on core courses required for medical technologist, it is necessary to set up a program to introduce forensic subjects for expansion of professional areas and activation which can promote employment of medical technologists.
\end{abstract}

Keywords: Biomedical Laboratory, Education, Forensic Medicine, Student

This is an Open Access article distributed under the terms of the Creative Commons Attribution Non-Commercial License (http://creativecommons.org/licenses/by-nc/4.0) which permits unrestricted non-commercial use, distribution, and reproduction in any medium, provided the original work is properly cited.

Copyright (C) 2015 The Korean Society for Clinical Laboratory Science. All rights reserved.
Corresponding author: Se-Hoon Jung Department of Neurology, Daegu Fatima Hospital, Daegu 41199, Korea Tel: 82-53-940-7790

E-mail: jjhaha@hanmail.net

Received: June 1, 2015

Revised $1^{\text {st. }}$ June 8, 2014

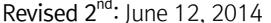

Accepted: August 20, 2015

\section{Introduction}

Forensic medicine recently has been receiving a great interest as regards scientific investigation on mass media such as soap operas and films. Korea is no exception to this, so an increasing number of people are dreaming of becoming a forensic science officer (Cho \& Jo, 2015). We made up for the weak points of previous studies on biomedical laboratory science requirement of forensic medicine which are essential for scientific investigation (Min et el., 2014) and implemented a measurement of the requirement of current students again. Scientific investigation may contribute at every stage of investigation, and it is making a critical contribution to the most important parts such as criminal identification and evidence collection. Particularly, development of up-to-date investigation equipment for scientific investigation and computer investigation technology can be included in the realm of scientific investigation with the scientific features, and a variety of academic fields contributing to scientific investigation include natural sciences such as chemistry, physics, biology, medical science, and electronic science and humanity, society, and fine arts such as psychology, sociology, statistics, accounting, and acoustics (Eom, 2014). Most of the parts that belong to the diversifying academic areas of 
scientific investigation are similar particularly with those of medical technologists which help doctors diagnose clinical specimens using medical test equipment with advanced scientific technologies. So, there is a trend to employee more medical technologists and nurses as scientific investigation agents.

As a result, 17 agents were employed on Nov. 30, 2005 and medicolegal death investigator system was introduced. The National Police Agency appointed those who have corresponding qualification from the area of medicine, nursing, biomedical laboratory science, and biology, and they completed a training course for certain period in National Forensic Service and Korea Police Investigation Academy before they were assigned at 16 local police agencies and police stations to work as professional crime scene investigators on dead body cases (Park, 2009). Among those, forensic medicine contributes to the protection of human rights through researching and providing answers for medical and scientific matters which are problematic by law. Thus, while care medicine extends human life and promotes heath of people, forensic medicine is a category of medicine to protect the rights of humans (Moon, 1994).

Moreover, forensic medicine is a practical field to resolve practical problems (Kang et al., 2007) Although requirement of medical technologist among scientific investigators in police agencies is increasing, education of forensic medicine as the fundamentals of scientific investigation is not sufficient in the course of biomedical laboratory science education. We carried out an analysis on survey targeting biomedical laboratory science in Daegu and sought for the students' awareness about forensic medicine and the requirement for education of forensic medicine in order to show the variety of the major courses for biomedical laboratory science which have been monotonously unified and to suggest a direction to deeply consider social phenomena through forensic medicine courses (Lim \& Kim, 2013).

\section{Materials and Methods}

This study carried out a survey with questionnaire targeting 100 students in the biomedical laboratory science of Daegu
Health College for 3 weeks from May 11, 2015 until April 1 to find the requirement for forensic medicine education for biomedical laboratory science seeking for their awareness and necessity of forensic medicine, for which data were collected by researchers who met respondents in person to explain the purpose of study and have the questionnaire filled out before collection (Yang et al., 2004). The questionnaire referred to the contents about awareness of forensic medicine and the contents about various experiences of crimes were adjusted and cited for better understanding of students (Yoo et al., 2012).

The content of survey was summarized based on the questions for requirement in the questionnaire. We carried out a preliminary survey with 10 students to check if the content fits the goal of study and completed the final version of questionnaire. The questionnaire consists of 7 questions for awareness of forensic medicine and 4 for requirement for forensic medicine. SPSS/Win 18.0 statistical package program was used to analyze the frequency in the data which was collected through survey.

\section{Results}

\section{Questions about awareness of forensic medicine}

In the questions about awareness of forensic medicine, 71 respondents $(71 \%)$ claimed to have heard about forensic medicine, 29 (29\%) answered no experience. For the question whether they are interested in forensic medicine, 8 respondents $(8 \%)$ were quite a lot interested, $32(32 \%)$ very much interested, 35 (35\%) moderately interested, 20 (20\%) a little interested, and 20 (20\%) have never been interested in forensic medicine, which represents that most of the students have heard about forensic medicine and majority of those are interested more than a little bit.

We questioned about the opportunities through which they became interested in forensic medicine and 61 respondents (61\%) found it through TV and mass media (forensic medical drama, miniseries, etc.), 3 (3\%) found interest through experience of criminal situations in their lives, $5(5 \%)$ were recommended by acquaintances, 17 (17\%) learned in classes or special lectures, 11 respondents (11\%) had miscellaneous 
reasons, and 3 (3\%) no answer (Table 1).

They were asked in a question if forensic medicine is helpful to biomedical laboratory science, and 58 (58\%) claimed that it is helpful, $10(10 \%)$ denied, and $32(32 \%)$ answered they do not know, showing the greatest number agreeing with its helpfulness.

Those we answered that it is helpful were asked in which area it is most helpful. 34 respondents (34\%) selected employment in relative area (scientific investigation agent), 3 (3\%) chose criminal situations in their ordinary lives, 21 (21\%) said it can be applied to clinical situations (medical malpractice, evidence collection from suspected patient), 15 respondents provided miscellaneous answers (3\%), and 27 (27\%) did not answer, and most of them thought forensic medicine is helpful for getting a job. We asked if they were aware of recruitment for clinical pathologists by the scientific investigation department of police agencies, and 84 respondents (84\%) answered yes, $15(15 \%)$ no, and only $1(1 \%)$ did not answer. Among those who answered yes, 45 (45\%) answered that they found it in their college classes, $17(17 \%)$ from seniors or acquaintances, $16(16 \%)$ through mass media (internet, TV, newspaper ads), 9 (9\%) through on-the-job education, other answers by (6\%), and 7 people (7\%) did not answer.

Most of the students agreed that forensic medicine may help them get a job, and the analysis showed that they find the information about recruitment for medical technologists by the scientific investigation department of police agencies from college classes, seniors or acquaintances, and mass media in order of percentage (Table 2).

Table 1. Questions on awareness of Forensic Medicine Education I

\begin{tabular}{|c|c|c|}
\hline Category & Division & N/Ratio(\%) \\
\hline Have you heard about forensic medicine? & $\begin{array}{l}\text { Yes } \\
\text { No }\end{array}$ & $\begin{array}{l}71 / 71 \% \\
29 / 29 \%\end{array}$ \\
\hline Are you interested in forensic medicine? & $\begin{array}{l}\text { Quite a lot } \\
\text { Very much } \\
\text { Moderately } \\
\text { A little } \\
\text { Never }\end{array}$ & $\begin{array}{r}8 / 8 \% \\
32 / 32 \% \\
35 / 35 \% \\
20 / 20 \% \\
5 / 5 \%\end{array}$ \\
\hline $\begin{array}{l}\text { By what opportunity did you have interest in forensic } \\
\text { medicine? }\end{array}$ & $\begin{array}{l}\text { TV. Mass Media } \\
\text { Experience of criminal situations } \\
\text { Recommended by acquaintances } \\
\text { Classes or special lectures } \\
\text { Etc. } \\
\text { No answer }\end{array}$ & $\begin{array}{r}61 / 61 \% \\
3 / 3 \% \\
5 / 5 \% \\
17 / 17 \% \\
11 / 11 \% \\
3 / 3 \%\end{array}$ \\
\hline
\end{tabular}

Table 2. Questions on awareness of Forensic Medicine Education II

\begin{tabular}{llr}
\hline \multicolumn{1}{c}{ Category } & \multicolumn{1}{c}{ Division } & N/Ratio(\%) \\
\hline Is forensic medicine helpful to biomedical laboratory & Yes & $58 / 58 \%$ \\
science? & No & $10 / 10 \%$ \\
& I don't know & $32 / 32 \%$ \\
If yes, in which area do you think it is most helpful? & Employment in relative area & $34 / 34 \%$ \\
& (scientific investigation agent) & $3 / 3 \%$ \\
& Criminal situations in ordinary lives & $21 / 21 \%$ \\
& Application to clinical situations & $15 / 15 \%$ \\
Are you aware that the scientific investigation de- & Etc. & $27 / 27 \%$ \\
partment of police agencies is recruiting medical & No answer & $84 / 84 \%$ \\
technologist? & No & $15 / 15 \%$ \\
If yes, how did you find it? & No answer & $1 / 1 \%$ \\
& College classes & $45 / 45 \%$ \\
& Seniors or acquaintances & $17 / 17 \%$ \\
& Mass media & $16 / 16 \%$ \\
& On-the-job education & $9 / 9 \%$ \\
\end{tabular}


156 Se-Hoon Jung. A Study on Educational Requirement of Forensic Medicine for Biomedical Laboratory Scienceal

Table 3. Questions on Requirement of Forensic Medicine Education

\begin{tabular}{llr}
\hline \multicolumn{1}{c}{ Category } & \multicolumn{1}{c}{ Division } & N/Ratio(\%) \\
\hline Is forensic medicine education necessary to biomedical & Certainly necessary & $24 / 24 \%$ \\
laboratory science & It will be helpful. & $70 / 70 \%$ \\
& Not necessary & $6 / 6 \%$ \\
In which curriculum should it be included & College curriculum & $34 / 34 \%$ \\
& Refresher training for clinical pathologists & $23 / 23 \%$ \\
& Education in clinical site itself & $15 / 15 \%$ \\
& Intensive major course & $20 / 20 \%$ \\
& Etc. & $4 / 4 \%$ \\
If necessary, how many hours? & $1 \sim 2$ hours & $36 / 36 \%$ \\
& $3 \sim 6$ hours & $27 / 27 \%$ \\
& $7 \sim 14$ hours & $10 / 10 \%$ \\
By whom they want to be taught? & 15 hours or more & $20 / 20 \%$ \\
& No answer & $7 / 7 \%$ \\
& Forensic medicine professor & $51 / 51 \%$ \\
& Medical examiner & $25 / 25 \%$ \\
& Medical doctor & $1 / 1 \%$ \\
\end{tabular}

\section{Questions about requirement for forensic medicine}

In the questionnaire about requirement for forensic medicine, the question asking if forensic medicine education is necessary to biomedical laboratory science was answered by 24 respondents $(24 \%)$ that it is certainly necessary, while $70(70 \%)$ that the education will be helpful and $6(6 \%)$ denied its necessity. For the question, if it is necessary, in which curriculum it should be included, 34 (34\%) claimed it should be included in college curriculum, 23 (23\%) in refresher training for clinical pathologists, $15(15 \%)$ in education in clinical site itself, 20 (20\%) in intensive major course, 4 (4\%) in other curricula, and 4 (4\%) Etc. For the question about hours of education when necessary, 36 respondents (36\%) answered 1 2 hours, 27 (27\%) 3 6 hours, 10 (10\%) 7 14 hours, 20 (20\%) 15 hours or more, and 7 (7\%) no answer. Regarding the necessity of forensic medicine education, 70 respondents (70\%) answered that the education will be helpful, 34 (34\%) selected college classes as the best curriculum for the education, and 1 2 hours of education was selected by the largest number of respondents, 36 (36\%). They were also asked by whom they want to be taught, and forensic medicine professor was selected by 51 respondents (51\%), medical examiner by $25(25 \%)$, medical doctor by $1(1 \%)$, police officer by $8(8 \%)$, and $11(11 \%)$ answered that it does not matter while 4 (4\%) no answer (Table 3).

\section{Discussion}

We carried out a survey on awareness and education requirement of the field of scientific investigation agent which has been receiving great attention. Particularly, it is forensic medicine that is the fundamental academic discipline to be a scientific investigation agent. In addition, secure a professional manpower has been growing an important issue make-or-break developing of scientific investigation. In particular, the medical technologist who has rudimentary knowledge of serology, physiology and chemistry has been already verified in the field of scientific investigation. But there are difficulty to select a workforce that has appropriate experience and long-term professional training. In its resolution, there is a need to devise incentives such as grants extra points for excellence graduates in the related subjects to the recruitment in the field of scientific investigation or forensic medicine. From the evidence, 2015 when post NPA(National Police Agency) civil service examination, the announcement by the appropriate qualifications as a nurse or medical technologist license holders, many of biomedical laboratory science have found a position as filed of scientific investigation.

Such as, it is important to step up national school collaboration to stay ahead of scientific investigation part through open academic subjects related forensic science and 
a forensic medicine class (Kwack \& Kim, 2009). Thus, we carried out a survey on requirement of forensic medicine education which is the fundamentals of scientific investigation in order to study on students' awareness and requirement of the forensic medicine subjects. Out of 100 respondents, in the result of survey for students' awareness of forensic medicine, $94(94 \%)$ answered that they were aware of it, which accounts for easer access and increasing interest regarding forensic medicine that can be naturally introduced by TV, mass media, forensic medicine dramas, acquaintances, classes, or special lectures.

In the result of awareness questionnaire, however, only 3 (3\%) out of 100 respondents answered that they became interested in forensic medicine and learned it from crime-related experiences in their ordinary lives for the question about the opportunity to know about forensic medicine, but what is significant as a result is that they could find it out of their ordinary lives. We think this result is one of the reasons why it is important to emphasize the importance of education and training through forensic medicine subjects in terms of crimes in our everyday lives. For the questionnaire about requirement, $70(70 \%)$ answered that education will be helpful, which shows high level of requirement. From this result, we can find that the requirement for expansion of various employment opportunities after education because a number of biomedical laboratory science have been made but the number of their graduates exceeds the demand of the market. Increasing awareness and interest of students do not fully account for the necessity of forensic medicine. We expect that the forensic medicine subjects will help learn about legal issues, apply laws in medical and scientific situations, and the biomedical laboratory science to deeply consider the social phenomena which derivate from the roles of human rights protection (Moon, 1994). Since this study shows the result of a survey which targeted students of biomedical laboratory science of Daegu Health College in Daegu region, it is not appropriate to generalize it as every student's. However, there has been no survey on awareness and requirement targeting biomedical laboratory science among other areas relevant to forensic medicine. We not only expect that this study serves as a basic survey reference about school environ- ment for similar researches, but also see more vigorous researches on requirement and utilization in many schools or schools where forensic medicine subjects have already been taught.

\section{요 약}

임상병리학과 학생들의 법의학 교육에 대한 인식개선의 방법을 개선하고, 활성화를 위한 방안을 제시할 목적으로 대구지역 대구보 건대학교 임상병리학과 학생 100 명을 대상으로 설문 조사를 실시 하여 법의학 과목에 대한 인식 및 요구도에 대한 항목들을 빈도 분 석하였다. 그 결과 대부분의 학생들이 법의학이라는 인식이 많이 높은 수준으로 조사되었다. 100 응답자 중, 법의학대한 인식 질문 에 94 (94\%) 그것을 알고 있다고 조사되었으며 법의학에 대한 기대 또한 높게 조사되었다. 현재 임상병리과 학생들에게서는 법의학 교 육의 인식 및 교육의 요구도가 매우 높았다. 따라서 대학 교육과정 에 임상병리사가 되기 위한 중점과목에만 집중하는 것보다 전문적 영역 확대 와 활성화를 위해 법의학 과목을 통해 특히 임상병리사 의 취업을 위한 방안으로 소개하는 프로그램의 도입이 필요하다.

\section{References}

1. Cho MS, Jo HB, Improvement of the Working System for Forensic Agents. The Journal of the Korea Contents Association. 2015, 15:188-192.

2. Eom JH, A Study on Train Plan For Copyright Infringement Forensics Professional in the Cyberspace. Journal of Security Engineering. 2014,11:591-604.

3. Kang DY, Gawk JS, et al. Forensic Medicine, 2007, p14. Jungmoonkak publishing, Seoul.

4. Kwack DG, Kim YH, Introduction of forensic science laboratories and development tactics for scientific investigation. The Korean Association of Police Science Review. 2009,11: 59-94.

5. Lee JS, General Considerations of Doctors-In-Training about Autopsies [unpublished master's thesis]. 2006, p14-15. Kyungpook National University, Daegu.

6. Lim CW, Kim JG, A Study on the Risk of Occupational Infectious Disease of Police Scientific Investigator (The Bacterial Culture of the Putrefying Dead Body Specimen). Korean J Clin Lab Sci. 2013,45(4):155.-158.

7. Min S, Ha YJ, Moon JY. Effect of Forensic Education and Autopsy Attitude of Nursing Student. J Korean Biol Nurs Sci. 2014, 16(3):211-218.

8. Moon GJ, Modern Forensic Medicine. 1994, p14. Ilmoonkak publishing, Seoul.

9. Park HY, The Future Direction of Korean Police Crime Laboratory. The Korean Association of Police Science Review. 
2009,11(2):137-141.

10. Yoo YS, Cha KS, Cho OH, Lee SK, Emergency Department Nurses' Recognition of and Educational Needs for Forensics Nursing Education. Korean J Adult Nurs. 2012,24(5):499-508.
11. Yang YY, Park HK, Park CY, Lee WK, Lee SH, Kwak JS, et al. Medical Students" Attitudes Toward Autopsy and the Effect of Their Attitudes Following a Forensic Pathology Course. Korean J Pathol. 2004,38:165-173. 